\title{
INTEMPERISMO DO TRABALHO E AS DISPUTAS TERRITORIAIS CONTEMPORÂNEAS
}

\section{Intemperismo of Work and the Contemporanean Territorial Disputes}

Prof. Dr. Antonio Thomaz Júnior

Universidade Estadual Paulista Júlio de Mesquita Filho Rua Roberto Simonsen, 305, Centro Educacional, CEP: 19060-900 - Presidente Prudente, SP - Brasil Tel/Fax: (+55 18) 32295375 / 32218212 - thomazjrgeo@terra.com.br

\section{$a \boldsymbol{a}_{a a}$}

\begin{abstract}
Resumo
Sob a regência do sistema metabólico do capital o trabalho se configura como trabalho estranhado, expressão designativa de uma relação social encimada na propriedade privada, no capital e no dinheiro. Com base nessa assertiva é que focaremos a dinâmica geográfica do trabalho e a constante (des)realização, no interior do metabolismo do capital como base para refletirmos criticamente um projeto para o Brasil, enquanto desafio. Preocupação de tamanho vigor e amplitude, reserva-nos atenção especial em relação aos efeitos destrutivos do processo de acumulação de capital, que corresponde à sua expansão ilimitada, em particular na sua forma atual, da globalização neoliberal. É necessário que consideremos a abrangência do tecido social e a urdidura das tramas sociometabólicas que o capital implementa, no devir do seu processo de territorialização. Por isso, a necessidade de se pensar alternativas radicais ou que coloquem outro horizonte histórico, para além do capitalismo e do metabolismo societário do capital.
\end{abstract}

Palavras-chave: trabalho; disputas territoriais; classe trabalhadora; sociedade emancipada do capital; socialismo

\begin{abstract}
Ruled by the metabolic system of capital, work has been shaped according to the model of stranged work, an expression that refers to a social relationship placed above private property, capital, and money. Based on this assertion, we will focus the geographical dynamics of work and the constant dis(realization) inside the metabolism of capital which is the fundamental issue in order to critically reflect on a Project for Brazil as a challenge. Such vigorous and wide concern claims our special attention to the destructive effects of the accumulation of capital that corresponds to its unlimited expansion, specially in regard to its current way, the neoliberal globalization. It is necessary to consider the width of the social web and the socio-metabolic contrivances that capital implements along its process of territorialization. Thus, there is a need to consider radical alternatives that present a new historical horizon, well beyond the capitalism and the societary-metabolism of capital.
\end{abstract}

Key words: work; territorial disputes; working class; capital-emancipated society; socialismo

\section{Resumen}

Bajo la regencia del sistema metabólico del capital el trabajo se configura como trabajo estrañado, expresión que designa una relación social fundada en la propiedad privada, en el capital y en el dinero. Partiendo de esta afirmación enfocaremos la dinámica geográfica del trabajo y la constante des(realización) dentro del metabolismo del capital como base para reflexionar críticamente un proyecto para Brasil, como un reto. Preocupación de tamaño vigor y amplitud nos demanda atención especial en relación con los efectos destructivos del proceso de acumulación de capital, que corresponde a su ilimitada expansión, en particular en su forma actual, la globalización neoliberal. Resulta necesario que consideremos la extensión del tejido social y la urdimbre de las tramas sociometabólicas que el capital implementa en el devenir de su proceso de territorialización. Por lo tanto, es necesario idear alternativas radicales o que ofrezcan otro horizonte histórico, más allá del capitalismo y del metabolismo societario del capital.

Palabras llave: trabajo; disputas territoriales; clase trabajadora; sociedad emancipada del capital; socialismo.

\section{aaCaa}




\section{INTRODUÇÃO}

Reconhecer as marcas territoriais do trabalho e seus significados topológicos, na sociedade em que vivemos; apreender os significados e os sentidos do trabalho, no seio da classe trabalhadora. Eis por onde estamos tentando construir nossas pesquisas - levadas a cabo nas últimas décadas, em várias regiões de São Paulo e do Brasil, como também algumas experiências na América Latina e na Espanha -, nas quais temos priorizado a metodologia da história oral, observação direta e análise de documentos, dissertações e teses. Por meio delas, fazemos um exercício constante para o redimensionamento teórico-conceitual-metodológico, com vistas a identificar, internamente à dinâmica geográfica do trabalho, sua constante (des)realização, o que nos está permitindo localizar reflexões sobre um projeto para o Brasil, desafio para este momento.

O século XX foi marcado por diversas crises, graves, amplas e mundializadas, seguidas pelas promessas de reforma da ordem, em nome da manutenção de um status democrático, caro e irreal para os trabalhadores. Afinal, a barbárie que selou esse processo interminável de reconciliação com a irreformalidade do capital, com fins de eliminar a miséria e a pobreza que recai sobre a maioria da humanidade, só faz retroalimentar os diferentes estágios de dominação de classe, que nada tem de acidental. Se não, como explicar as diferenças abissais entre os $20 \%$ mais ricos e os $20 \%$ mais pobres ter saltado de 30/1, em 1960, para 80/1, em 2010? Ou seja, um sistema social de desigualdade estrutural incorrigível e incuravelmente injusto ou que sustenta a incômoda verdade de que o capital é incapaz de reconhecer seus próprios limites e que as reformas que se sucedem só fazem remediar as contradições e os perigos mais cruéis de sua incontrolabilidade, que perniciosamente impõem uma ordem social ainda mais injusta e iníqua.

No plano imediato do horizonte, põe-se a questão da natureza da crise econômica e social de nossos dias, que já não pode ser negada. No entanto, é necessário destacar que a crise que temos de enfrentar é estrutural, profunda e a cada momento ganha mais gravidade, tendo amplitude global, ou seja, afeta a totalidade de um complexo social, em todas as suas relações com as partes constituintes, da mesma forma que com outros complexos. Ao contrário da crise não-estrutural, pois, que afeta apenas partes do complexo, não colocando em risco a estrutura global. O roteiro de uma crise financeira que provocou a crise mundial teve início no final de julho de 2007, constituindo, por isso, uma crise do regime de acumulação predominantemente financeirizada, iniciada no final da década de 1980. Chesnais (2011) vai mais fundo, quando pondera que essa enorme crise "[...] é a conexão entre a crise econômica e financeira e a crise ecológica mundial em suas diferentes dimensões" .

Isso significa dizer que a persistência da crise estrutural do modo de reprodução sociometabólica do capital, que define os limites últimos da ordem estabelecida, se deve por radicar na inteireza do sistema do capital e que tudo abrange. Em concordância com Mészáros (2011a), "[...] deve-se também enfatizar que a crise estrutural de nosso tempo não se originou em 2007 com a 'explosão da bolha habitacional dos Estados Unidos', mas sim, pelo menos, quatro décadas antes” . (p.3).

O panorama aterrador/devastador que intemperiza a sociedade e o trabalho está afinado à ideologia do desenvolvimento, desgraçadamente adjetivada de sustentável, e, neste alvorecer do século XXI, reforça sua tinta no aumento intenso da pobreza no mundo ou do empobrecimento de trabalhadores, inclusive empregados. Porém reforçado nos grilhões de desempregados e descartados do mercado de trabalho, da mesma maneira que a extremada destruição da natureza, dos ecossistemas se intensifica, sob o escopo de ações sustentáveis. O que significa dizer que sob o capitalismo o trabalho como atividade vital se configura como trabalho estranhado, expressão designativa de uma relação social encimada na propriedade privada, no capital e no dinheiro.

E é exatamente nesse ambiente da apropriação de riquezas que a terra e a água ocupam lugar central, quando se põe em questão a sobrevivência do planeta, a produção de alimentos, a exploração e a comercialização de matérias-primas etc. Impõe-se de modo marcante, nesta primeira década do século XXI, elementos novos e repletos de significados no tocante às disputas em torno da terra e da água ou do acesso a esses bens no mundo e, particularmente, no Brasil. 
A esse respeito, o capital tem à disposição elementos imprescindíveis para a marcha expansionista dos seus negócios. Além de contar com os favorecimentos dos investimentos públicos e também privados, e por isso disputa apoios, cabe colocar em evidência que os bons resultados obtidos são complementados pelo acesso às melhores terras (planas, férteis, com localização favorável e logística de transportes adequada). Mas não somente, pois o sucesso do empreendimento como um todo requer a garantia de acesso à água, seja superficial (grandes rios, reservatórios de hidrelétricas, lagos), por meio de intervenções, via de regra, represamentos de cursos d'água, seja subterrânea - sobretudo os aquíferos.

É importante apontarmos ainda que o acesso à água pode ser mais eficiente ou obter melhores resultados, quando os mecanismos de controle estejam adequados à conservação de solos que, por sua vez, poderão garantir maior infiltração das águas das chuvas, melhorar a reposição ou recarga dos aquíferos, das nascentes, das veredas, dos rios etc.

Partindo desses pressupostos, podemos ponderar que, apesar das especificidades do segmento agroindustrial canavieiro, em relação às tantas outras formas de expressão do capital, no que tange à dinâmica, às estratégias reprodutivas, de controle do trabalho, e à aposta da sua constante precarização/fragilização, há semelhanças. No entanto, é no interior dos conflitos (territoriais) que temos o fio condutor das ações dos sujeitos envolvidos nesse cenário. Em decorrência, as ações que antepõem trabalhadores $\mathrm{x}$ capital, as fissuras intercapital reveladas pela necessidade de terras planas, férteis e com disponibilidade hídrica - portanto, aptas à mecanização -, e entre os próprios trabalhadores são, por excelência, os exemplos das disputas por território que revelam o conteúdo e os significados do processo expansionista do agrohidronegócio em geral.

Está ocorrendo a superposição ou mesmo a disputa direta entre outras frações do capital agroindustrial, com destaque para os investimentos na atividade agroindustrial canavieira sobre a mesma porção territorial até então hegemonizada pela soja, milho e mais recentemente o avanço da monocultura do eucalipto. Ou seja, as frações do território em disputa (intra e intercapital) - com a participação crescente, inclusive de grupos estrangeiros - expressam não somente uma nova geografia do espaço agrário, no Brasil, mas consolidam o poder de classe do capital sobre as melhores terras agricultáveis e planas do país, e da maior incidência de disponibilização de água de subsolo da América Latina.

Esse processo recente de expansão do agrohidronegócio, que se consolida em praticamente todos os biomas brasileiros, se fortalece com intensidade no Cerrado, na Amazônia e em algumas áreas do Semi-Árido do Nordeste, concilia interesses dos conglomerados agroquímico-alimentar-financeiros, ensejando a produção de produtos para exportação (commodities), tais como a soja, milho, algodão, eucalipto e mais recentemente o álcool de cana-de-açúcar, o fortalecimento da pecuária em grandes extensões de terra, a verticalização das granjas (suínos, frangos). Atualmente, vincula-se também, de forma direta ou consorciada, a outros grupos econômicos, aos negócios da construção de barragens e hidrelétricas.

Ao mesmo tempo em que inocultável, esse processo de (des)realização do capital atinge duramente a sociedade, de sorte que a natureza também passa a ser imperceptível, tendo em vista as travagens e os impedimentos ideológicos previstos no receituário neoliberal que lhe confere legitimidade.

Se pudéssemos retornar ao século XIX e buscássemos nos apologetas liberais da época, como John Stuart Mill, a sustentação dos dilemas do crescimento econômico, teríamos como amparo a eternalização das determinações históricas do sistema, com extensão para as características problemáticas e destrutivas.

E o que dizer das perspectivas para o século XXI? São melhores ou piores?

$\mathrm{O}$ argumento para o momento impõe que consideremos que as mesmas características sistêmicas do crescimento, intrínsecas à própria natureza do capital, encimadas na alienação e expropriação do trabalho, revelam as faces de um sistema de controle mais sofisticado e amplo, com base na nova fase 
do imperialismo hegemônico global, de cariz norte-americano, todavia mais destrutivo e perigoso.

O que podemos sintetizar a respeito dos descolamentos construídos entre a produção de bens ou valores de uso, para a satisfação, como fator ontologicamente absoluto da condição humana , para a situação da produção de valores de uso, ou a essência da antípoda do trabalho autônomo, livre, é, em essência, a conversão da atividade laborativa em elemento de mediação de segunda ordem, agora, pois, metamorfoseado por meio da materialidade da geografia do trabalho assalariado, fetichizado e alienado. Nesse período específico da história da humanidade, a subversão das necessidades humanas aos imperativos da valorização do capital e à reprodução do valor de troca atingiu em profundidade as mediações de primeira ordem, que foram, de maneira nefasta, sendo substituídas pelos elementos fetichizadores próprios do sistema de metabolismo social do capital. Por isso, o trabalho alienado passa a compor a forma dominante para a valorização de capital.

Esses novos elementos de controle social e metabólico fazem com os meios se tornem os fins últimos, sendo que, por sua vez, os fins ontológicos da humanidade (produção de valores de uso) são transformados em meios subsumidos aos tais fins reificados.

É, pois, encimada pela dinâmica metabólica, suas contradições e (des)construções territorialmente expressas nos desterreamentos, migrações, espoliações e demais formas de consolidação da exploração/dominação/sujeição e de controle social, que o capital impõe a "[...] nefasta divisão hierárquica e social do trabalho que perpetra a subordinação estrutural do trabalho ao capital" (ANTUNES, 2011, p.76). A sintonia principal desse processo de desenvolvimento, protagonizado pelo capital e que viabiliza a produção capitalista, significa, em essência, produção de mais valia, absorção de trabalho excedente. Em acréscimo, isso não conduz somente ao empobrecimento da força humana de trabalho, "[...] despojada de suas condições normais de desenvolvimento e de exercício físico e moral. Produz, além disso, a extenuação e a morte prematura da mesma força de trabalho" (MARX, 1982).

Assim, a característica contingente do sistema do capital, de erigir-se na medida em que o trabalho alienado se consubstancia em negatividade, ao afirmar o processo de produção de capital no qual o produto do seu trabalho não lhe pertence, como também não se reconhece no próprio processo laborativo, e fundado no preceito de crescer inexoravelmente ou perecer - que, diante de desvios de rota, pode parecer facilmente corrigível -, é, na verdade, essencial para se provar que a ordem reprodutiva do capital é insuperável e insolúvel. Por isso, estamos em concordância com Mészáros (2004, p.82), quando indica que “[...] uma negação adequada da alienação é, portanto, inseparável da negação radical das mediações capitalistas de segunda ordem”.

Em consequência, o necessário repensar dessa situação nos mobiliza a reorientar as práticas de produção, a fim de resguardar os objetivos sociais essenciais da reprodução, e não propriamente apostar tratar-se de uma regra universal, para a qual não há alternativa. Assim, acreditamos, no nosso tempo, que a criação de uma ordem social alternativa não seja somente desejável, mas sobretudo, necessária e urgente para a sociedade do futuro e, com isso, o substrato para um projeto para o Brasil.

\section{PELA BASE DO TECIDO SOCIAL, COMPREENDER AS FISSURAS E AS URDIDURAS...}

Os trabalhadores especializados/desqualificados do fordismo, que, durante décadas, ocuparam a cena, foram sendo substituídos pelos trabalhadores completos, não mais os artesãos do capitalismo da Primeira Guerra. Se o novo nos remetia (remete) ao toyotismo e, mesmo diante das dificuldades de apurar definição precisa, especialmente pelo fato de se desenvolver a partir de uma nova base técnica do sistema do capital - e isso é demarcatório, do ponto de vista histórico -, não podemos nos esquecer de que, no bojo da $3^{\text {a }}$ Revolução Científico-Tecnológica, que começou a dar os primeiros passos após a Segunda-Guerra e só se manifestou nas décadas de 1970-80, tem-se a (re)criação de um novo trabalhador, com novas qualificações e natureza multifuncional (polivalente).

As marcantes mudanças que ocorreram no ambiente produtivo e gerencial do mundo capitalista fazem florescer o cenário que se concretizará numa nova ordem espacial moldada pela empresa 
flexível, que traz consigo novas substâncias quanto aos mecanismos e padrões de acumulação e de geração de valor.

No contexto da precarização e flexibilização do emprego associado às crescentes mudanças na organização do trabalho, tem-se que as ocupações ligadas às tecnologias da informação e da comunicação (TCIs) - em essência de natureza informacional e imaterial - marca o teletrabalho ou popularmente identificado como trabalhador de Call Center, como uma categoria particular no cenário da degradação imposta pelo metabolismo do capital. Como indica Rosenfield (2011), a organização sujeitos envolvidos nas modalidades de teletrabalho, "poderia se enquadrar nas características do pós-taylorismo por analogia à injunção paradoxal" [...], ou seja, ser autônomo e se enquadrar nas normas. (p.176).

É nessa armadura da liofilização que o caráter parcelar, fragmentado e o traço de manualidade do trabalho taylorista, em contraposição ao trabalho de gerência (intelectual), cede lugar à nova marca de precarização, agora, pois, mediada por mecanismos de controle que se propõem suavizar as linhas divisórias anteriores, ou seja, o ambiente de trabalho é mais participativo, assim como aparentemente menos dividido. No entanto, mais desregulamentado, precarizado, diante de novas formas, inclusive regressivas de contratação/pagamento, disseminadas por meio da informalização, entremeadas pelas novas decisões em relação à organização produtiva, como a terceirização, os artifícios da exploração do trabalho, com a retomada de dispositivos sutis que praticizam a mais-valia absoluta, num mundo marcadamente mais técnico e informacional, notadamente afirmado com a presença crescente do cibertariado .

Mais ainda, em tempos de século XXI, a polivalência e a multifuncionalidade, algo diverso do que prevaleceu na empresa taylorista e fordista, atesta que o trabalho que as empresas implementam nasce da sua fissura. A fase da "desespecialização multifuncional", do "trabalho multifuncional", expressa a intensificação dos ritmos, tempos e processos de trabalho, que se territorializam nas diversas instâncias, áreas e setores da atividade laboral, isto é, tanto no mundo industrial, quanto nos serviços e no agrohidronegócio.

De gorilas amestrados a polivalentes, multifuncionais, da obrigatoriedade - ideologicamente metamorfoseada pela imposição da voluntariedade dos trabalhadores, para se somarem à concepção de trabalho em equipe -, mediada pela sutileza do controle da parceria com o capital, têm-se novos mecanismos de alienação/estranhamento do sistema de metabolismo do capital, no século XXI, voltados, pois, para formatar um perfil profissional, responsável e sobretudo flexível às demandas do mercado; "[...] aparentemente menos despóticos e mais interiorizados" (ANTUNES, 1999). Ou ainda, no formato de gestão e controle efetivado pelo capital, no ambiente do modelo flexível, liofilizado, as empresas, por meio de instrumentos degradantes, convertem "[...] os trabalhadores e as trabalhadoras em déspotas de si mesmos!" .

É oportuno argumentar que a marca fundante do estranhamento é o próprio significado que o trabalho tem como componente do capital, ou seja, em essência "a própria transmutação genética do trabalho em capital". Ou ainda, "o capital aparece como realização efetiva de trabalho, mas essa realização efetiva é a objetivação do próprio trabalho, que aparecerá então, a um só tempo, como estranhamento e alienação". (RANIERI, 2001, p. 61).

É no interior do ambiente de mudanças nas formas de organização da produção e seus impactos espaciais que temos novas formas de controle do trabalho e, consequentemente, novos significados e sentidos para a dimensão material e subjetiva dos trabalhadores. A nova polissemia que caracteriza essa etapa impacta de forma direta a classe trabalhadora e, por meio dos nossos estudos, podemos complementar e ampliar nossos conhecimentos com outros aprendizados, ou seja, a marca destrutiva do processo social redefine e potencia os papéis da migração do trabalho para o capital, do mesmo modo que intensifica a desqualificação e renomeia a qualificação em outros setores de atividade, sem contar o componente étnico-racial que demarca as novas identidades dos segmentos historicamente mais excluídos, como os negros, mestiços e mulheres, além do forte traço da feminização, 
no ambiente do trabalho. Da mesma forma que a necessidade precípua do capital de estabelecer e organizar as técnicas para cimentar o poder hierárquico e autoritário sobre o trabalho, lhe assegura o controle e extração/apropriação do saber operário, sendo, pois, essa, uma das vias de realização a desqualificação do trabalho .

Isso pressupõe, dada a abrangência do fenômeno do trabalho, a nosso juízo, não admitir que uma única teoria, ou autor, será capaz de compreender/explicar essa complexa trama de relações e fornecer instrumentos analíticos. Todavia, não se trata de apostar num mix teórico, mas de reconhecer as limitações dos referenciais explicativos diante do universo do trabalho, no qual convivem, pari passo, formas essencialmente capitalistas de trabalho (assalariado típico), formas mais precarizadas, tais como as diferentes formulações da informalidade, as formas temporárias, para nos referirmos aos part-time-workers, temporary-workers, casual-workers, vinculados à formulação fundante de Huw Beynon, de "hyphenated workers", ou trabalhadores hifenizados . Da mesma maneira que o teletrabalho, as expressões da terceirização, formas não capitalistas, como o camponês (posseiro, extrativista, pescador artesanal, arrendatário/meeiro etc.), toda a plêiade da informalidade, trabalho autônomo, domiciliar etc.

Por outro lado, não devemos deixar de registrar que comparece em cena, veladamente ou não, o desinteresse por esse assunto e a consequente transferência de responsabilidade, sob o argumento de que, em não havendo possibilidade de responder ou contemplar os cuidados (objeções) e intransponibilidades teóricas, que não se ultrapasse o sinal. Quer dizer, colocar em questão os limites da teoria, as barreiras que dificultam os debates, a necessária reelaboração conceitual e, mais ainda, as intenções de avançar e transpor os esquemas explicativos conhecidos, pode não ter acolhimento seguro.

312 Não obstante, não se pode renunciar à coerência teórica e rigidez metodológica, mas, com as atenções voltadas para os desafios postos para a maioria dos homens e das mulheres, diante do destrutivismo desenfreado do capital e a iminência da emancipação da classe trabalhadora, temos também que colocar em questão outras habilidades, que não só aquelas que nos têm permitido resguardar os princípios e os valores intelectuais. Para tanto, é indispensável que associemos os reais significados da incontrolabilidade do capital e o fato de que a sociedade só pode se transformar pela via da luta de classes, o que exige de nós atenções para a atualidade do tecido social do trabalho, intensamente fragmentado.

É por esse caminho que nos propomos identificar as diferentes formas que expressam a resistência ao capital, todavia não mais restritas aos parâmetros do assalariado tradicional, ou do operário taylorista/fordista, mas extensiva às demais formas de explicitação do trabalho, e também não apenas limitadas ao "chão de fábrica", que, em conjunto, crescem em todas as escalas geográficas e em magnitude. A respeito das sociabilidades que não se restringem ao circuito da ralação essencialmente capitalista, podemos tomar os exemplos das práticas socioculturais que envolvem diretamente as comunidades à memória da terra, ou seja, a terra vista não como mercadoria, mas sim território de vida, da própria existência, o que significa que, ao perdê-la, perde-se juntamente a possibilidade da existência.

Poderíamos, oportunamente, reforçar a ideia de que as formas de exploração da força de trabalho, implementadas pelo capitalismo contemporâneo, como pondera Harvey (2004), ao analisar as formas de acumulação - com referência a Marx e Luxemburgo - por meio do conceito de acumulação por espoliação, tem-se que, no momento de mundialização do capital, não se fazem ausentes os mecanismos e procedimentos utilizados quando do momento da acumulação originária ou primitiva, como algo exclusivo e único, correspondente à fase inicial do capitalismo e que desapareceu, no decorrer do tempo.

É por isso que somente as pesquisas nos têm possibilitado demarcar essas preocupações e revelar por meio da autocrítica, pública, que as dificuldades de compreensão desse processo nos têm impedido de apreender as especificidades do ser social que trabalha em diferentes formas labo- 
rativas e constrói visões/compreensões de mundo, quase sempre relegadas pelos sindicatos, pelos partidos, pelos intelectuais etc. O que indicamos anteriormente por teoria espacial do trabalho não será produto de definições apriorísticas ou axiomas, mas sim da nossa capacidade de apreender os desafios e tensionamentos que estão colocados no interior da dinâmica geográfica do trabalho, da luta de classes. São essas, pois, as exigências para nos situarmos no ambiente da centralidade do trabalho e, considerando a amplitude das ações de resistência, a ideia de que há sujeitos capazes de mudar o mundo e, tendo em vista a trama polissêmica que lhe dá sentido, no século XXI, apreender as possibilidades emancipatórias na perspectiva de classe da classe trabalhadora.

Em termos operacionais, seria o mesmo que reconstituirmos as capilaridades internas e os modos de realização da existência do trabalho pelas diferentes habilitações laborativas, bem como as relações de trabalho que um mesmo trabalhador pode desempenhar, ao longo de um mesmo ano fiscal. Os significados e sentidos dessas vivências, do ponto de vista de classe, eis a questão que não se põe a priori, senão no próprio processo social.

Garantir coerência a esse pensamento requer, além do exercício constante da autocrítica, que tenhamos criatividade para entender a complexa trama espacial (apreender o fenômeno do trabalho por meio dos princípios lógicos da localização, distribuição etc.) e as contradições da dinâmica territorial que envolve e sufoca a sociedade e os trabalhadores, no século XXI. A frequência, o ritmo, a intensidade com que mudam de lavra (habilitação/profissão/enquadramento sindical), migram cotidianamente em busca de emprego e melhores condições de vida, se constantemente (cultural, social e geograficamente), se empobrecem etc. Enfim, há toda uma mobilidade e fluidez do trabalho, que revela os ataques constantes do capital e dos Estados, mas também está refém da rigidez dos postulados e daqueles que não querem enxergar e aceitar a necessidade de ampliar os horizontes dos sonhos e da utopia emancipadora, para além dos manuais e, possivelmente, das cartilhas. Esse processo incide tanto sobre os assalariados "puros", trabalhadores temporários, por conta própria, informais, agricultores camponeses, quanto sobre os contingentes que estão à frente das ações de luta pela terra.

Assim, podemos apreender a plasticidade do trabalho, no plano da explicitação no cotidiano, ou reconhecer suas singularidades e as materialidades de cada experiência, avançando para o plano do concreto em pensamento, síntese de múltiplas determinações, tendo como pressuposto contribuir para a formulação de investigações e estudos críticos e direcionados à construção de referenciais emancipatórios e anticapital, capazes, portanto, de romper com o estranhamento.

Por conseguinte, apesar de estabelecermos a prevalência ou o primado da dimensão ontológica do trabalho, é imprescindível que possamos construir nossa compreensão, a partir da práxis teoricamente orientada, com as atenções voltadas para a superação das fragmentações da práxis social do trabalho, além da dimensão teórica, que reside no entendimento/tratamento parcelário das frações do trabalho, combinando com as diretrizes da sua divisão técnica.

Nesse sentido, ainda que formulações tais como desenvolvimento das forças produtivas e os efeitos sobre as relações de trabalho, a reestruturação produtiva do capital e as mutações no universo do trabalho, a fragmentação da práxis social do trabalho, a alienação do trabalho, desafiem ou requeiram atenções específicas, estão em questão as redefinições em vigência no processo de acumulação e reprodução do capital, em âmbito internacional.

\section{...E é nos ambientes de crise que as (des)identidades e que os projetos se (re)constroem...}

É importante que busquemos as sintonias entre crise econômico-financeira e seus enraizamentos sociais e os espalhamentos geográficos pelas diferentes regiões geográficas e porções do território; esse é, pois, o caminho para conhecermos e dimensionarmos a amplitude de um fenômeno que potencializa e dialeticamente constrói-reconstrói o que temos denominado civilização da barbárie ou, como comparece na literatura, com aproximações indicadas como crise de civilização, que atinge em cheio a sociedade salarial, fazendo com que os explorados e os dominados não somente 
estejam mergulhados nela, mas sobretudo porque afundarão cada vez mais.

Como aponta Chesnais (2011, p.188):

De imediato, os que são assalariados vêem-se confrontados com um conjunto de medidas tomadas por governos e empresas cujo objetivo é não jogar o peso da crise em cima deles, como usar a mudança das relações de força em proveito do capital que resulta do aumento do desemprego e, com isso, agravar ainda mais as condições da exploração. Em um horizonte temporal mais distante, os explorados e os dominados terão de enfrentar a interpenetração [...] entre a crise econômica mundial, a crise de alimentos que atinge as populações mais vulneráveis e os impactos sociais de uma crise provocada pelas mudanças climáticas, vista como crise das condições de reprodução social [...] e à degradação da biosfera.

Para complementar essa ideia, tomamos o quadro social e político que é negligenciado, esquecido, omitido e que abriga os bilhões de homens e mulheres que continuam à margem da classe trabalhadora, mas que, de fato, estão se envolvendo nas lutas, nos confrontos. Em particular, nos últimos cinco anos, com as mudanças macroestruturais no formato produtivo das matérias-primas de origem agropecuária, em nível planetário, na agroindustrialização e na circulação/distribuição dos cereais nobres (soja, milho) nas mãos de seleto grupo de transnacionais, os quais também fazem parte da equação da produção de biodiesel - e isso está alimentando a voracidade inflacionária no setor de alimentos, à casa de 50\%, quando se leva em conta a realidade de 2007 para 2008, e fazendo da fome a principal chaga da humanidade, em pleno século XXI.

A evidente vinculação entre a expansão das áreas de plantio das commodities com a disponibilização dos recursos terra e água tem sido imprescindível para as estratégias do capital. Assim, a posse da terra e da água nos remete a refletir o papel do Estado no empoderamento do capital e seus efeitos, no quadro social da exclusão, da fome e da emergência da reforma agrária e da soberania alimentar. É dessa complexa e articulada malha de relações que estamos focando esse processo, no âmbito do agrohidronegócio, por onde nos propomos entender os desafios para a sociedade, para os moradores das cidades e dos campos, ou seja, a dinâmica geográfica da reprodução do capital no século XXI e os cenários que põem, para os trabalhadores.

A fragilidade do tecido social é tamanha que somente a disparada dos preços dos alimentos no mundo, de 2007 para 2008, aumentou em 75 milhões o número de famintos, os quais totalizam 925 milhões de pessoas, segundo depoimento do diretor da FAO. O executivo acrescenta que será preciso investir U\$30 bilhões por ano, para duplicar a produção de alimentos e acabar com a fome, ainda que a questão central não seja a falta de alimentos em si, mas a falta de renda e de recursos para aquisição, por parte dos famintos.

O medo que setores importantes da burguesia e do grande capital têm manifestado publicamente está fundamentado nos estrangulamentos das contradições sociais, expressos criminosamente pela quantidade crescente de famintos e das mobilizações que "pipocam" por vários cantos do planeta (Egito, Filipinas, Brasil, Nicarágua, México, Índia). Se não bastasse o cinismo da afirmação de que "é necessário barrar a imoralidade da produção de agrocombustíveis em detrimento da produção de alimentos", qualquer pessoa desavisada poderia ser ludibriada. Nesse depoimento, o diretor-gerente do Fundo Monetário Internacional (FMI), Dominique Strauss-Kahn, expõe as fissuras e disputas internas aos setores dominantes, mas que, por contarem com o apoio e sustentação política em nível internacional, dos grandes conglomerados transnacionais e dos Estados, que, apesar de manifestarem interesses setoriais - como o Brasil, que reivindica o fim dos subsídios - defendem nichos de mercado e não propriamente ações concretas que garantam acesso aos alimentos para as populações pobres e empobrecidas.

É importante assinalar também o estranhamento oriundo dos mecanismos de dominação e controle, associado ao "jogo" de interesses presentes no interior das diferentes instâncias da sociabilidade dos trabalhadores (no próprio local de trabalho, na lida pela sobrevivência, nos partidos políticos, nos sindicatos, nos movimentos sociais etc.), que constrói fissuras e fragmentações. Todavia, é nesse 
campo de rupturas e disputas que os trabalhadores (assalariados, posseiros, ribeirinhos, camponeses etc.) constroem suas organizações e põem em práticas lutas de resistência e pleiteiam por meio de diversas ações acesso a terra, Reforma Agrária, emprego e, mais recentemente, acesso à água.

Por conseguinte, nessa mesma área onde se consolida o projeto hegemônico do capital, que, mediante a combinação de seus interesses patrimoniais em relação à propriedade da terra e à logística produtiva e mercadológica, quando se põe em cena a garantia de acesso à água numa dupla ação privatizante, tem-se ainda o protagonismo dos trabalhadores, dos movimentos sociais envolvidos em ocupações de terra, que reivindicam a retomada dessa porção do território para a produção de alimentos sãos para o abastecimento interno, à escala regional. Sem contar que parcelas dessas mesmas porções de terra, além de serem reivindicadas para Reforma Agrária, já dispõem de inúmeros assentamentos rurais e milhares de famílias acampadas, originários da atuação e luta dos movimentos sociais.

O que estamos inserindo, nessa já complexa trama de relações, são as disputas pelo acesso à água como ações que poderão juntar interesses comuns dos trabalhadores, como já o faz para o capital. Porém, não nos iludamos a respeito das formas e procedimentos diferenciados quanto ao acesso à água e aos requerimentos que cada qual exige para tal fim. Isto é, enquanto o capital utiliza mecanismos e procedimentos técnicos e conta com recursos e infraestrutura públicos, para construção de reservatórios e mesmo acesso aos reservatórios de hidrelétricas, tais como os canais coletores e de adução de água, e mesmo por conta própria também os constrói, os camponeses empregam parcialmente a água subterrânea, por meio de perfurações pouco profundas, inadequadas tecnicamente quanto à vazão, tempo de duração, o que não lhes garante condições para fazer uso da água em escalas mais amplas.

A mistura de interesses distintos e de enraizamentos econômicos e políticos diferenciados dos agentes econômicos e da sociedade, em relação à cobrança da água, ainda é marcada por polêmicas, contradições e controvérsias. A rejeição dessa iniciativa junta no mesmo flanco grandes empresas, produtores agrícolas de diferentes condições econômicas, produtivas, patrimoniais e demais setores. Esse assunto, que coloca todos os agentes econômicos na mesma condição, apesar de as magnitudes a serem cobradas apresentarem diferenças, e diante da manutenção histórica de privilégios, no Brasil, para os setores hegemônicos, revela, sobretudo, que está faltando nesse debate a priorização, por parte da sociedade, das instâncias organizadas e representativas dos trabalhadores, os movimentos sociais etc. Em síntese, o que é importante, estratégico e imprescindível para o desenvolvimento social, produção de alimentos e para a qualidade de vida dos seres vivos e da natureza em geral? Se assim não for, a iniciativa da cobrança da água, mesmo tendo em tese o fim de garantir o pagamento de um bem público, de uso comum, como previsto na Lei 12.183, de dezembro de 2005, está sendo combatida por obstar os interesses empresariais, do capital, nas suas diferentes expressões, sendo que a repercussão que produz, nos segmentos sociais voltados para a produção da subsistência e garantia do fornecimento de alimentos de primeira necessidade, é de desestímulo e de mais sobrecarga tributária.

Nossos estudos estão sinalizando que a maior parte das terras férteis agricultáveis está sob o controle dos empreendimentos do agrohidronegócio, sendo que a cana-de-açúcar ocupa lugar de destaque, não somente em São Paulo, mas nas porções do território objeto da expansão recente ou que se consolidam nesse circuito, tais como Mato Grosso do Sul, Triângulo Mineiro, Sul-Sudoeste de Goiás, Noroeste do Paraná, o que denominamos Polígono do Agrohidronegócio no Brasil. Os efeitos podem ser sentidos na retração das áreas de produção de alimentos, a começar pelo feijão, arroz e a produção de leite.

Entretanto, não poderíamos deixar de observar que não se trata de uma tomada de posição contrária à produção de etanol pura e simplesmente, até porque partilhamos, com os movimentos sociais populares em nível internacional (ambientalista/ecológico, sindical), das bandeiras que empunharam há décadas - a das alternativas renováveis de fontes energéticas. 
A substituição das fontes de energia não renováveis (petróleo, gás natural, carvão mineral, atômica) tinha como motivação apostar num outro modelo de organização da sociedade, calcado na sustentabilidade ambiental/social da produção/fornecimento de energia, em bases sociais e organizativas, que pudessem responder ao bem-estar de produtores e consumidores. Mas, diante de mais essa tomada de assalto do grande capital das ideias originais dos grupos e setores sociais que reivindicavam autonomia e esquema político e econômico sustentável para a produção de energia, o que se tem é a hegemonização desse tema, pelos interesses dos grandes conglomerados empresariais oligopolistas que subverteram o ideário inicial, a partir do momento em que fizeram valer seus interesses econômicos de controlar a produção/distribuição/circulação de energia e, consequentemente, usufruir de mais uma possibilidade para a maximização dos seus lucros.

Em decorrência, ao mesmo tempo em que o capital impõe mudanças na matriz energética dos países para prevalecer seus interesses econômicos, estratégicos, logísticos, ele o faz através de princípios excludentes, amplificando em demasia as desigualdades sociais, a concentração de riqueza, de terra, de renda e de poder. As variações de lugar para lugar, na adoção/sofisticação de formas regressivas, nas relações de trabalho, na subordinação de camponeses e médios produtores à sistemática oligopólica, evidenciam toda a indiferença do capital com o meio ambiente, por meio das práticas destrutivas e degradantes que, juntos, impactam profundamente nas formas de uso/ exploração do território.

Dessa maneira, não se trata de utilizar argumentos extemporâneos, já que a essência do problema não é a produção propriamente dita dos agrocombustíveis ou, em particular, do etanol, mas os expedientes, o formato e a estrutura da produção, e o conteúdo do projeto social lhe dá fundamento para estarem assentados em grandes extensões de terra, na exploração do trabalho, e totalmente desatrelada de um programa nacional e sustentável de produção de alimentos, edificado nas unidades de produção familiar e enraizado nos referenciais da soberania alimentar dos povos.

É nesse turbilhão que o abandono dos fundamentos conservacionistas, a garantia da "socioética biodiversidade" e a participação social plena na formulação/execução de "estratégias públicas para obtenção de alternativas de energia renovável, em especial a partir de biomassa”, são radicalmente modificados e travestidos, e se tem a prevalência do modelo concentracionista e destrutivo do capital, renovado nos anos 1990, sob o império neoliberal. Esses são os principais sinais que mostram o caráter cada vez mais destrutivo do processo de acumulação capitalista, em escala global. A isso se somam os transgênicos e, sobretudo, os interesses dos conglomerados agroquímico-genético-alimentar-financeiros. Nossos estudos têm possibilitado apontar o quão pantanoso é esse assunto, diante da desinformação, dos interesses difusos e da eficiência do sistema de controle do tecido social pelo capital, pois a contaminação e destruição protagonizadas pelas lavouras de produtos transgênicos às formas de plantio e sistemas produtivos "tradicionais" acusam tamanha gravidade para a saúde pública, para a reprodução da vida e para o futuro das espécies. A essas práticas e aos fundamentos do metabolismo do capital tem-se a sociedade em risco, com o futuro incerto.

Portanto, um projeto para o Brasil, preocupação de tamanho vigor e amplitude, reserva-nos atenção especial para os efeitos destrutivos do processo de acumulação de capital, que corresponde à sua expansão ilimitada, em particular na sua forma atual, da globalização neoliberal. É necessário que consideremos a abrangência do tecido social e a urdidura das tramas sociometabólicas que o capital implementa, no devir do seu processo de territorialização. Por isso, a necessidade de se pensar alternativas radicais ou que coloquem outro horizonte histórico, para além do capitalismo e do metabolismo societário do capital, ou da lógica do lucro, da acumulação, da reprodução das desigualdades e do destrutivismo imanente.

A exemplo de Löwy (2010), que sinaliza o ecossocialismo como alternativa, produto da convergência crítica entre a reflexão ecológica, a reflexão socialista e a reflexão marxista. A crítica à ecologia não socialista ou à ecologia capitalista/reformista que tenciona reformar estruturas condenadas, capazes de responder às campanhas midiáticas milionárias, para tornar o "capitalismo mais 
verde, mas respeitoso ao meio ambiente", requer que se coloque em primeiro plano a propriedade dos meios de produção e a precípua sinalização do projeto de classe.

Longe de modelos fáceis que podem cumprir papéis predefinidos, pensar um projeto para o Brasil nos põe atentos às lacunas da ausência da crítica radical das experiências tecnocráticas, burocráticas, de sorte que o marxismo continua como referência de vida, de concepção de mundo e fundamento para a construção revolucionária. Em síntese, trata-se de transformar não só as relações de produção, as relações de propriedade, mas também a estrutura das forças produtivas e do aparelho produtivo. Para nós, é impossível separar a ideia de uma nova sociedade, de um projeto para o Brasil enquanto uma estratégia de luta, da ideia de uma civilização da solidariedade, de uma nova matriz energética, um novo paradigma de civilização alternativo.

\section{A DESTRUTIVIDADE DE UM PROCESSO SOCIAL CONDENADO...}

Em essência, é necessário que coloquemos em evidência o fato de que a ausência da dimensão humana para se avaliar a viabilidade do processo de produção/reprodução - apenas considerado como fim em si mesmo ou a acumulação de capital - garante as condições para o avanço do crescimento destrutivo, voltado para a expansão do lucro.

É como se disséssemos que o trabalho e a mediação entre o homem e a natureza, aliás, ponto de partida da humanização do ser social, no entanto, sem o trabalho não seria possível que a vida cotidiana se reproduzisse. Sem embargo, se a vida humana se resumisse unicamente ao trabalho, o ser social ficaria refém ou aprisionado a uma única das múltiplas dimensões possíveis.

Além disso, existe a crença de que a ciência, a técnica, a tecnologia, a razão instrumental desfrutem de protagonismo para garantir a missão civilizatória ocidental, as ondas da modernidade, como denomina Castel (1998), e, com isso, o equilíbrio estratégico no planeta atrai ao seu entorno até aqueles que se pronunciam contra a barbárie do capital. Poderíamos dizer: todo cuidado é pouco! Porém, o que é importante demarcar é que os ganhos de consciência são também construídos ao longo dos embates e não in vitro, como se estivéssemos numa redoma: ao contrário, no próprio embate e disputa de ideias e de construção da emancipação social.

A coesão desse sistema do capital, como afirma Mészáros (2002), é, portanto, um sistema sociometabólico que subverte, historicamente, os valores de uso (a produção livre da natureza em si) em valor de troca. Isto é, à capacidade natural do homem se relacionar com a natureza, pelo trabalho, para a produção da riqueza humano-social, que o autor denomina "mediações de primeira ordem", se sobrepõem os objetivos da acumulação e reprodução do capital, expedientes fundamentados no processo de alienação e estranhamento dos homens, compreendidas como "mediações de segunda ordem". Isso nos mostra que as "mediações de segunda ordem", momento em que o capital subtrai do homem seu trabalho, retiram-lhe as mediações que estabelece com os outros homens e, por conseguinte, desconfiguram sua condição genérica de homem, de ser social, assegurada pelo trabalho (MÉSZÁROS, 2002, p.179-180).

Como componente intrínseco da natureza humana, o capitalismo estaria sempre em expansão, superando a alternância periódica das conjunturas e das crises, o que, conforme Luxemburgo (1976), constitui feição específica do modo de produção capitalista, mas não o movimento em si, removendo resistências, derrubando barreiras e ultrapassando fronteiras, tudo pelo desenvolvimento econômico e social e pela manutenção e garantia da "harmonia" que o mercado pressupõe.

Esse processo amplia ainda mais a exploração dos trabalhadores, fortalecendo sistemas de controle político e trabalhista, favorecendo a prática da perseguição à filiação e luta sindical. E, com isso, a instabilidade do assalariamento temporário em condições precárias, bem como a informalidade, tem-se o alargamento das hordas de ocupantes de terra, que se somam a outros milhares de trabalhadores excluídos e precarizados, os quais, juntamente com suas famílias, apostam na alternativa do confronto com o capital, latifundiários, que, além de promoverem todas as mazelas 
sociais, monopolizam igualmente a terra e a água.

Por esse caminho, sob o jugo das mediações do capital, produzem-se homens diferentes que passam a ser definidos individualmente e que se relacionam de modo conflitante, agora apartados do seu trabalho, uma vez que, depois de se submeterem aos imperativos do mercado, serem consumidos pelo capital, retornam já na forma de força de trabalho.

Podemos pensar, ainda, que a necessária vinculação entre o processo social (metabólico) ou a totalidade do sistema do capital e a manifestação territorial do fenômeno (do trabalho) é o que apoia e funda o estranhamento e, no seu interior, a especificidade (do conjunto) das relações sociais. Em síntese, o trabalho não perde sua essência, sua condição humana criadora de valores de uso, mas apenas se (des)realiza, na realização do capital. O que ocorre é nada mais do que uma inversão de sentido, para garantir a reprodução e valorização do capital. Quer dizer, o trabalho subsumido à produção de valor é essencial para o capitalismo, mas não necessariamente para a humanidade. É por essa razão que as formas de realização desse trabalho são, em essência, destrutivas.

A título de exemplo, quando consideramos o divórcio existente entre o trabalhador e seu trabalho, há aí a sintonia com o fetiche da mercadoria. No entanto, o que dá conexão com o estranhamento (nas suas diversas formas de externalização), para, em outro nível de realização do trabalho estranhado, reiterar a separação entre o trabalhador e sua força de trabalho, é o próprio metabolismo do capital.

Essa subordinação teórica das categorias é imprescindível para podermos compreender a teoria do valor, na razão direta da vigência dos paradigmas produtivos e as respectivas manifestações do fenômeno do trabalho, especialmente porque vivemos um momento histórico marcado por redefinições de grande amplitude, no interior da classe trabalhadora. É por dentro da lógica do valor, ou da necessidade da crescente reprodução ampliada da riqueza abstrata, que os processos geográficos se materializam, pois, dado o seu fim em si mesmo como sentido, os conteúdos concretos são subsumidos à equivalência monetária, no universo de uma sociedade produtora de valor.

Se o estranhamento impossibilita ou dificulta a passagem dos flashs de luz que poderiam iluminar as contradições e o nefasto quadro de destruição das experiências de vida comunitárias e das organizações camponesas, encobre igualmente o caos que se instala nos setores mais dinâmicos da economia, os quais vivenciam casos de aguda exclusão e de (des)realização do trabalho. Em alguns países e regiões, esse movimento de desmonte do trabalho, após meados da década de 1990, particularmente nas cidades, está intensificando e ampliando a ruptura das habilitações/profissões encimadas à formalidade contratual, ou rompendo/redefinindo as blindagens da divisão técnica do trabalho, fundada no modelo fabril/industrial.

Dessa maneira, estaríamos repondo em questão a fluidez com que assalariados, desempregados, camelôs, camponeses, posseiros, autônomos, índios, refazem constante e intensamente o desenho societal da classe trabalhadora. Isto é, esse movimento extrapola, inclusive, os rígidos limites entre o que é ser, num dia, servente de pedreiro, numa temporada metalúrgico, numa safra cortador de cana, operário da construção civil nas obras do PAC e, em outros momentos, vivenciar as diferentes modalidades da informalidade, ser ambulante, ocupante de terra e, nessa condição, também se assalariar temporariamente etc.

Quando nos ocupamos com a (des)realização e as novas identidades do trabalho territorialmente expressas na plasticidade que se refaz continuamente, estamos preocupados com os desdobramentos para os trabalhadores da constante redefinição de profissões, habilitações, especializações, inserções autônomas etc., entremeada, em vários casos, com experiências de despossessão. Essa trajetória de fragmentações atinge em cheio o trabalho, de sorte que são essas as evidências mais profundas do estranhamento a acrescentarem desafios à compreensão do trabalho, na perspectiva de classe.

Se buscarmos em Marx e Engels (1982), em A Ideologia Alemã, vamos encontrar que a propriedade privada funda o trabalho estranhado (e vice-versa), entretanto, a determinação reflexiva de propriedade privada é a divisão hierárquica do trabalho. Em decorrência, os autores asseveram: 
“Assim, divisão do trabalho e propriedade privada são expressões idênticas: a primeira enuncia em relação à atividade, aquilo que se enuncia na segunda em relação ao produto da atividade" (p.79). Por consequência, é do processo social de proletarização, diga-se processo sistêmico do metabolismo social do capital, que emerge a condição de existência da civilização do capital. Dito de outra forma, o processo de proletarização, que marca a ocidentalização do mundo, protagoniza um movimento sócio-histórico estrutural e impõe um tipo humano submetido às coisas ou ao poder das coisas, ou seja, o homem alienado ou homem desefetivado como sujeito.

Num mundo cada vez mais contaminado pela perversidade do processo de reprodução do capital e pelo embaralhamento ideológico e conceitual, teremos (temos) que reconhecer, desde já, por meio das fraturas que identificam um sem número de relações vivas (desconectadas) do trabalho, a malha de significados que pode repor em questão a ruptura com a lógica do capital, em escala mundial. Em Antunes (1999), temos as pistas para vincular a economia informal à terceirização, subcontratação, trabalho temporário, parcial, precário, desemprego estrutural. Quer dizer, é esse processo de fragmentação da classe trabalhadora em diversos segmentos que tem prejudicado o entendimento de pertencimento de classe, diante dessa realidade movediça.

Nessa perspectiva, o ataque direto aos proletários, imanente à estratégia de dominação do capital, inscrito de forma geral, com a diminuição crescente de seu efetivo em todo o mundo, não nos autoriza a afirmar e defender que o trabalho perde centralidade, até porque a teoria do valor continua edificando o processo sociometabólico do capital e, por outro lado, não deve ser o esgarçamento das relações de trabalho estritamente assalariadas e a crescente participação da informalidade a decretar o fim do trabalho. Em outros termos, se faz parte da lógica do capital o permanente revolucionamento das forças produtivas, em algum momento desse processo, pode colocar em questão o próprio processo de acumulação.

É essa constante remodelação de sentidos e significados do ser que trabalha e que no, dia-a-dia, se envolve na lavra, que assumimos como objeto para focar o exercício da plasticidade, tanto nos campos quanto nas cidades. O rico e instigante exercício teórico e conceitual, presente nos assuntos que estamos desenvolvendo, nos têm permitido ampliar e enriquecer os horizontes de compreensão sobre o universo do trabalho.

Essa preocupação comparece de modo mais elaborado, todavia como exercício e não formulação acabada, em "A Geografia do mundo do trabalho na virada do século XXI" . As expressões da plasticidade do trabalho injetam novos elementos para repensarmos o entendimento de classe trabalhadora, no Brasil do século XXI , com as atenções voltadas para qualificar o seguinte questionamento: quem são os sujeitos com incumbência histórica para transformar estruturalmente a sociedade vigente?

O desenho plural de sua composição e os elementos compósitos dos desafios para entendermos o trabalhador informal, o temporário, o camponês, as legiões de desempregados que cumprem papéis variados, não somente como exército de reserva, porém, como sujeitos que exercem papel de destaque no seio do conflito de classes, de confronto com o capital e expressões da burguesia, estão muito mais próximos da noção de classe trabalhadora. De fato, a classe trabalhadora hoje, sob o jugo da financeirização, da reestruturação produtiva, da microeletrônica, da crescente informalização, é mais complexa, heterogênea, ampliada e disseminada espacialmente, o que exige de nós recursos analíticos condizentes, para compreendermos a diversidade das suas formas geográficas ou, de fato, reconhecermos suas singularidades no âmbito da totalidade viva do trabalho.

Nesse ínterim, é importante reforçarmos que o apego a priori a determinados pressupostos, sem que efetivamente sejam compreendidos no interior do processo contraditório da luta de classes, é que nos leva a acreditar que, pelo fato de o trabalhador proletário contrapor-se radicalmente ao capital, a ele teríamos que continuar delegando a responsabilidade revolucionária e nele deveríamos debitar a resposta da indagação central que nos move, na nossa caminhada intelectual: quem são os homens e as mulheres que são capazes, no século XXI, de transformar/emancipar a sociedade e 
imprimir outro curso histórico, para além do capital? E mais, qual o significado mais profundo da mudança estrutural qualitativa a ser construída/realizada com amplitude histórica global e que afete a totalidade da humanidade? O diferenciador nesse processo, a consciência político-ideológica de classe do trabalho, ou a tomada de consciência para si, de classe, do proletariado, na contemporaneidade, é secundarizado, e o que tem sido explicitado são as defesas teóricas desse primado, sem que tenhamos os registros dessa construção.

A esse respeito, uma primeira demarcação de discordância pode ser observada através da posição defendida por Lessa (2007), pois, em várias passagens do texto "Trabalho e proletariado no capitalismo contemporâneo", expressa sua fidelidade às formulações originais de Marx, particularmente ao Livro I e, nesse caso, argumenta que "[...] a origem de toda riqueza que circula na sociedade é o trabalho, mais exatamente, o trabalho proletário [...], é o único que produz um novo quantum do conteúdo material da riqueza social, que será acrescido ao montante do capital social global", portanto, a única classe que exerce a função social de converter a natureza em meios de produção e de subsistência (MARX, 1982, p.171). Em decorrência, o autor está respaldando sua compreensão no fato de que a classe trabalhadora é composta somente pelo proletariado, e explicita essa posição, quando vincula o fato de ser essa

[...] a única classe da sociedade capitalista que produz o "conteúdo material da riqueza", que "produz" o "capital", pois é ela a única classe que exerce a função social de converter a natureza em meios de produção e de subsistência. [...] Ela é, na sociedade capitalista, a única classe cujo "trabalho produtivo" "produz" não apenas mais-valia, mas também "capital", que produz originalmente toda a riqueza social, o "capital social total". (MARX, 1982, p.179).

320 Por outro lado, é componente vivo na formulação de Mészáros (2007) relativizar a restrição, fundada na ideia original de Marx, para o século XXI, de que o(s) agente(s) social(is) da mudança ainda seja(m) delegado(s) aos trabalhadores manuais. Nem Marx propugnou essa restrição, segundo o autor - porém, isso parece não ser consenso -, mas o que nos interessa é que compareçam as preocupações e o cuidado necessário com as mudanças em marcha e que fazem precipitar novas realidades e dimensões ontológicas dos homens e das mulheres envolvidos na complexa trama de relações do trabalho.

O cumprimento à rigidez das formulações marxianas eleva a defesa das contradições objetivas de classe entre o proletariado e os demais assalariados. Lessa (2007) vai mais longe, quando argumenta que a circunstância de os assalariados não proletários viverem da riqueza que a burguesia expropria dos proletários os estimula a manter a defesa e a manutenção do capitalismo, pois “[...] atuam predominantemente como força auxiliar na reprodução do capital", particularmente com o apego à propriedade privada, fato historicamente registrado sempre que esta foi objeto de ameaça pela luta de classe. Para o autor, "[...] os assalariados não-proletários possuem, portanto, identidades e contradições tanto com a burguesia como com o proletariado. Sua função social, de um modo geral, é auxiliar na reprodução das relações sociais burguesas” (LESSA, 2007, p.180).

Aqui cabem duas lembranças da história. Em primeiro lugar, se os exemplos que comprovam essa afirmativa ocorrem, assim como abundam aqueles que a negam, por que o autor não os considera, particularmente levando em conta a realidade atual, nos diversos cantos do planeta? A essa pergunta não nos cabe responder, todavia, ponderamos que as definições a priori, que tanto nos têm atormentado, mais uma vez comparecem - e também pela via de avaliações apressadas, mutila-se o próprio conteúdo dinâmico da dialética marxista, ao desconhecer a negatividade e a positividade do trabalho, ou seja, fundamentado em Kurtz (1999) poderíamos, equivocadamente, defender que positivar o trabalho produtor de coisas significaria hipostasiá-lo para o presente e para o futuro.

Em segundo lugar, a limitação do conceito de classe trabalhadora à identidade do trabalhador manual, assalariado, produtor de mais-valia ou, ainda, o entendimento mais amplo que reconhece o conjunto dos assalariados (produtivos e improdutivos) não contemplam contingentes cada vez 
mais expressivos de homens e de mulheres que não se enquadram nessas premissas, situando-se na franja da exclusão suprema, ou seja, os sem emprego, sem trabalho, sem profissão, sem casa, sem terra, sem perspectivas, os famintos que crescem à velocidade da luz, sendo que $70 \%$ deles, segundo a ONU (2006), estão no campo, vinculados a terra: são camponeses empobrecidos, comunidades tribais, atingindo, na contemporaneidade, aproximadamente um bilhão de pessoas.

Essas evocações da história exigem de nós a responsabilidade de deixar claro que é necessária atenção especial às definições preestabelecidas, porque a própria dinâmica da realidade e a voracidade/impiedosidade do moedor de carne refaz constante e intensamente a realidade social do trabalho.

Lessa (2007) admite que a expansão das relações capitalistas para todos os poros da sociedade tem aumentado as contradições em relação à burguesia. Contudo, por ser o proletariado a única classe rigorosamente não parasitária, é ela que tem a missão de derrubar o modo de produção capitalista e abolir as classes. Ou, num esforço de síntese, o autor, ao reservar ao proletariado a missão revolucionária, retoma a polêmica na qual entende residir um fosso no âmbito do bloco que defende a centralidade do trabalho, a identificação de um "subcampo" que traz à tona, na contemporaneidade, a indagação de se há ou não distinção entre proletários e trabalhadores, ou se "[...] seriam os trabalhadores a classe revolucionária por excelência" e não mais a restrição ao proletariado, como invocado nas formulações marxianas.

Em outros termos, trata-se tão-somente de comprovar, por meio das pesquisas, que a resistência e os processos de luta e de confronto não são protagonizados, na contemporaneidade, ou não têm no epicentro o proletariado ou os sindicatos como canchas de resistência ou verdadeiras escolas de socialismo e exemplos de construção revolucionária. Ou seja, não é por essa via que se expressam as principais disputas territoriais da luta de classes registradas nas pesquisas recentes, tampouco oriundas dos nossos registros.

Com isso, não estamos defendendo a ideia de que, como não há mais os antagonismos da época de Marx, conforme argumentado por Lessa (2005), “[...] então não há mais espaço para a contraposição radical com o capital, tampouco para a revolução”. Ao contrário, o que está em relevo é a necessidade inequívoca de repensarmos, por dentro da dinâmica territorial do trabalho, quais são as condições em que o conflito de classe se expressa, na sociedade, retrato, necessariamente, dos conflitos e da realidade da centralidade do trabalho, no século XXI, enfim, as apreensões das pesquisas recentes.

Desse modo, esse assunto não somente ganhou a centralidade das nossas pesquisas e das atenções, em sentido geral, mas também nos mobiliza a buscar respostas para a indagação que insistimos perseguir, e que já é o mote da nossa caminhada, quer dizer, quem são os homens e as mulheres capazes, no século XXI, de transformar/emancipar a sociedade e imprimir outro curso histórico para além do capital? Se há algum sentido prático mais eficaz e historicamente sintomático, do ponto de vista da classe trabalhadora, que ganha protagonismo, nesse intento, quem são os sujeitos revolucionários? Ou, ainda, o que coesiona esses sujeitos do trabalho? Os sindicatos? Os partidos políticos? Os movimentos sociais? As igrejas? As Organizações Não Governamentais (ONGs)? As Redes Sociais?

Com isso, estamos enfatizando que, se a vida humana requer trabalho humano e também seu caráter contestador/emancipador, ela deve recusar o trabalho desumano que estranha e degrada o ser social que trabalha. Em acréscimo, é em meio a essa dimensão contraditória que, ao mesmo tempo em que emancipa, aliena, em que humaniza, degrada, em que libera, escraviza, fazendo com que nossos estudos sobre a sociedade, pela via do trabalho, sejam imprescindíveis para a decifração das formas de controle, dominação, resistência e emancipação do trabalho. Essa dupla dimensão presente nos ambientes de externalização do trabalho, adverte que estamos no caminho correto quando rejeitamos tratamento unilateral ou dual a esse movimento dialético e contraditório do trabalho. É no interior do processo que fundamentamos a imprescindibilidade e emergência da extinção dos 
pilares estruturadores do capital e do trabalho alienado, e que uma nova forma de sociabilidade seja construída, com base, pois, num sistema de metabolismo social para além do capital.

Essa dupla dimensão é estruturante das complexas tramas por meio das quais o trabalho se externaliza, na contemporaneidade, e revela o intemperismo dessa relação, cujas formas de degradação , o capital aumentou sobremaneira, nas últimas três décadas, repercutindo diretamente na saúde do trabalhador a elas submetidos, bem como suas enfermidades específicas recorrentes. Além disso, repercutem nas disputas territoriais em torno das quais é recorrente discutir um projeto para o Brasil.

As pesquisas desenvolvidas nas últimas décadas, em várias regiões do Estado de São Paulo, do Brasil e no exterior, priorizando-se diversas metodologias qualitativas, tais como a observação direta e a análise de documentos, dissertações e teses defendidas em várias universidades e centros de pesquisas, nos possibilitam argumentar e refletir sobre as condições de trabalho e saúde como dimensão prioritária das formas de exploração e dominação vigentes. E se, na era mais avançada, informacional/digital, designada de terceira revolução industrial, temos as revelações das combinações espectrais/regressivas, como, por exemplo, teletrabalho ou o cibertariado, de um lado, e os contratos de trabalho por produção e as formas assemelhadas de trabalho escravo ou a escravidão em termos, nos canaviais, em São Paulo, no coração do agrohidronegócio canavieiro brasileiro, de outro, o capital não pode eliminar o trabalho vivo.

As metodologias de pesquisa estão subordinadas à importância da realização das ações empíricas, aliás, condição necessária para a apreensão do movimento da realidade social do trabalho. A observação teoricamente orientada dos pesquisadores é o que fará a diferença, tendo em vista as aproximações entre as diferentes realidades do trabalho. A íntima relação entre esses procedimentos metodológicos é a condição para apreendermos as contradições e os tensionamentos que coexistem à realidade do trabalho que nos propomos investigar.

Assim, não se pode esperar que o espaço geográfico deveria ser entendido e tido a partir da mera demarcação das coordenadas geográficas, ou da dimensão escalar do fenômeno em apreço, sem que se indiquem, com clareza e contundência, as (des)identidades dos sujeitos sociais que protagonizam, em meio aos conflitos e disputas territoriais em marcha, os conteúdos e significados das suas ações e projetos de sociedade. Entendemos que a opção pela priorização das diferentes facetas e expressões concretas do trabalho, que conseguimos incluir nas nossas reflexões a categoria trabalho, o conceito de trabalho, sua abrangência e riqueza de significados, e a necessária delimitação teórica e explicativa, no âmbito da Geografia.

Com isso, desejamos compreender, por meio dos nexos e atributos que constituem seus princípios lógicos (localização, distribuição, extensão, distância, posição, escala), os conteúdos contraditórios e os tensionamentos, no âmbito da dialetização do movimento categorial/conceitual da Geografia, que refaz metodologicamente as mediações entre paisagem, território e espaço, e, com isso, debater a noção de pertencimento de classe da classe trabalhadora.

\section{..E DAS CONDIÇÕES DE TRABALHO E SAÚDE DO TRABALHADOR...}

Em essência, as interfaces entre dinâmica territorial, formas de dominação e relações de trabalho, formas de uso da terra, gestão da água e saúde ambiental, ocupam lugar central na análise das consequências do modelo de desenvolvimento econômico integrado à dinâmica de valorização do capital. O movimento do trabalho, o movimento da natureza e o movimento da saúde ganham importância analítica, por entendermos que é possível outra relação sociedade-natureza, a ser construída por dentro das disputas territoriais e de classe, sob o pressuposto de apontar alternativas voltadas ao desenvolvimento sustentável da sociedade e da natureza. Aqui, é oportuno retomarmos Mészáros (2002), para assegurarmos que nenhum dos imperativos das mediações de primeira ordem necessita de hierarquias de dominação/subordinação que venham configurar "[...] o sistema de metabolismo societal do capital e suas mediações de segunda ordem” (p.22). 
Assim, surpreendem-se as doenças associadas às transformações recentes da expansão do capitalismo, seja no campo (por meio dos monocultivos, intoxicações via aplicações de fortes cargas de agrotóxicos, da perda da biodiversidade, ganhos por produção etc.), seja nas cidades (com todos os agravantes que incidem sobre a penosidade e o ambiente de trabalho desprotegidos contra os contaminantes, ganhos por produção, subempreita etc.) (RICKLEFS, 2009).

Nessa perspectiva, as diferentes formas de exploração/subordinação/dominação/sujeição/controle do capital sobre o trabalho e suas ramificações para a sociedade estão associadas aos impactos sobre a natureza de maneira geral (THOMAZ JUNIOR, 2009). No caso específico das atividades agrárias, isso se expressa por intermédio da extensividade da jornada, péssimas condições de trabalho, transporte inadequado, negligência do capital em relação aos EPI's, descumprimento dos contratos de trabalho e das Normativas Regulamentadoras (por exemplo, a NR-31), dentre outros fatores.

Sob os novos horizontes das doenças ocupacionais (risco, mutilações, contaminação, intoxicação, morte), estão associados a invisibilidade social das doenças relacionadas ao trabalho , os agravos à saúde dos trabalhadores, devido à ineficiência da política social pública. Tudo isso reverbera na reconfiguração das relações de produção e de trabalho, com rebatimentos também nas formas de (super)exploração e de escravidão, associadas, portanto, às condições degradantes de labor, bem como maior intensidade e exaustividade das jornadas e do ritmo de trabalho. E, mais, como a assistência à saúde, de direito universal, torna-se mercantilizada, exclui progressiva e crescentemente a saúde do trabalhador da proteção estatal e, com isso, tem-se a minimização dos programas sociais públicos.

Vis a vis, as doenças ocupacionais relacionam-se menos com as disposições biológicas e anormalidades orgânicas, que têm incidência isolada sobre trabalhadores, que, fundamentalmente com a organização e a realização da atividade laboral. Isto é, sob determinadas condições que, nas sociedades contemporâneas, primam pela flexibilização, intensificação dos processos exploratórios, ligados aos descumprimentos da legislação trabalhista, acentuando ainda mais a degradação do trabalho. Nesse sentido, entender o par saúde-enfermidade encimado à categoria trabalho implica sintonizá-lo à totalidade do processo social de trabalho (produção e reprodução da vida) e ao conjunto das relações sociais que os homens estabelecem entre si, enquanto sujeitos históricos.

\section{A DESERTIFICAÇÃO SOCIAL E OS DESAFIOS PARA UM PROJETO PARA O BRASIL}

É por isso que o processo de degradação do trabalho é heterogêneo, com sentidos específicos para os estáveis, semiestáveis, instáveis e descartados, e igualmente cambiante de setor para setor, expressando-se em combinações que vão da superespecialização à multifuncionalidade/polivalência das formas efêmeras/provisórias à perenidade do trabalho, aliás, característica mais rara nessa barbárie imperante no século XXI.

Assim, se a valorização do valor depende exatamente da exploração do trabalho vivo, humano, ao poupar trabalho de forma radical, como se presencia por meio da $3^{\text {a }}$ revolução técnico-científica, esse fenômeno, em consequência, estaria afetando a lei do valor, pelo fato de evidenciar que o trabalho abstrato perde de modo crescente e ampliado a capacidade de ser a medida da própria acumulação de capital.

E o que pensar sobre os movimentos migratórios do trabalho para o capital, no Brasil, que se consolida e também são renovados e ganham novas dimensões, no século XXI? O desenho/redesenho dessas novas rotas migratórias está sendo redefinido, em essência, pela estimulação das políticas públicas, sobretudo no ambiente do Programa de Aceleração do Crescimento (PAC), instituído em janeiro de 2007, pelo governo Lula.

As obras de infraestrutura que absorvem $65 \%$ dos $\mathrm{R} \$ 507$ bilhões, da fase I e mais o aporte da fase II, estão potenciando obras, com alcance para saneamento, construção de pontes, estradas, recapeamento, grandes obras de engenharia, tais como Usinas Hidroelétricas (UHE), bem como as Pequenas Centrais Hidrelétricas (PCH). E ainda se somam às obras previstas para a Copa Mundial 
de Futebol de 2014 e das Olimpíadas de 2016.

As contradições desse processo indicam estarmos diante de um movimento que conta com novos vetores, os quais impactam diretamente a força de trabalho. Os principais corredores migratórios, ou Estados/regiões emigratórios (Maranhão, Piauí, Norte de Minas Gerais, Bahia, Alagoas), que há mais de duas décadas abastecem as demandas do corte da cana-de-açúcar no Centro-Sul ou, mais propriamente, São Paulo, e as colheitas de outros produtos agrícolas (laranja, café morango, frutas), a partir de 2007, sinalizam alguns desvios de rota, para Rondônia, Mato Grosso, Goiás, Tocantins, Rio Grande do Sul, Pernambuco, Ceará. Ou seja, apesar da migração do trabalho para as atividades do agrohidronegócio (particularmente canavieiro), novos elementos estão indicando novas combinações dos deslocamentos territoriais.

A continuidade das pesquisas nos tem possibilitado inferir esses questionamentos e, diante das dificuldades de obtenção de informações confiáveis para ultrapassarmos o sentido da especulação, no tocante à migração do trabalho para o capital - apesar de a busca por qualidade de vida e menos violência possam ser complementares -, nos atemos às informações recentes divulgadas pelo IBGE , a respeito da migração interna. É possível inferir que há movimentos de retorno que indicam novas esferas de atração por emprego nos locais (Estados/regiões/municípios de origem). Tanto é que o Nordeste passou a segurar população e a atrair população de retorno.

Essas mudanças divulgadas indicam que os migrantes tendem a diminuir, apenas com base no perfil revelado para os 3,36 milhões de pessoas que viviam em regiões diferentes daquela de origem, em 2000, parametrizados nos 2,86 milhões, em 2004, e nos 2,05 milhões, em 2009. É importante relativizar o peso dessa afirmação, quando consideramos que parte significativa dos trabalhadores que migra em busca de trabalho não consta nos registros oficiais, porque esse processo não respeita as normativas trabalhistas previstas em lei. Sem contar que, com a aplicação dos recursos do PAC, em diferentes regiões do Brasil, como já enfatizamos, o movimento migratório dos trabalhadores tem sido diretamente atingido.

Em meio a essas limitações, vamos considerar, portanto, os nexos que nos permitam problematizar o assunto, com as atenções para as complexas tramas do século XXI, vinculadas, pois, à compreensão das funções vitais das mediações de primeira ordem, diante do propósito de se pensar um projeto para o Brasil. Daí a imprescindibilidade das necessidades humanas (valor de uso) ante sua antípoda face mercantil (valor de troca), por conseguinte a sintonia entre os níveis de produtividade, os instrumentos de trabalho e o conhecimento/manipulação das técnicas, mediante a prevalência de um sistema de trocas pautado na satisfação individual e coletiva.

Dessa maneira, somos desafiados a ampliar os horizontes de compreensão do tecido social aos formatos conhecidos, ou reconhecer a necessária redefinição dos papéis sociais dos sujeitos que protagonizam a construção da sociedade. Mais que isso, é necessário subverter a ordem metabólica societal, a fim de que os novos papéis dos sujeitos sejam portadores das novas funções sociais.

Isso nos põe atentos a um repensar sobre o movimento que transcorre no interior do tecido do trabalho. Ou seja, sobre a constante passagem da condição de assalariados (operários puros e proletários) para informais, da mesma maneira que setores do campesinato, não com a perda/negação do status de rebeldia e de capacidade de lutar contra o capital, mas de mudança na forma, no conteúdo e nos procedimentos de reação e resistência da classe trabalhadora. Pensamos que não é propriamente com o enquadramento do trabalho à categoria de semiproletário, lumpen, condição de proletariedade, ou mundo operário sem a classe correspondente, como demarcação para continuar mantendo o distanciamento desses contingentes da composição da classe trabalhadora, assim como com a defesa de seu descentramento, porque senão nos escapará o entendimento do rico e contraditório processo de redefinição das lutas e o conteúdo da dinâmica geográfica atual do trabalho, da renovação da composição da classe trabalhadora, no século XXI.

Tampouco poderíamos imaginar que o fim do trabalho abstrato, constantemente atingido pelo próprio capital que o criou e que o destrói, pela via da substituição de força de trabalho por máqui- 
nas, sem que isso se processe por meio de revolução e emancipação de classe, corresponde apenas a uma manifestação da barbárie.

O retorno dos sistemas de trabalho doméstico, que se aproxima do que definimos como trabalho domiciliar e que, como imaginava Marx, seria substituído no capitalismo avançado, ao contrário, é exatamente no interior de sua recomposição na virada do século XXI, na fase da microeletrônica, que o "[...] enorme crescimento das práticas de trabalho do setor informal por todo o mundo capitalista avançado, represente de fato uma visão bem sombria da história supostamente progressista do capitalismo" (HARVEY, 1992).

Podemos afirmar que o capitalismo globalizado apresenta um movimento intenso e contraditório de integração, fragmentação, polarização, que redimensiona constantemente a diferenciação dos espaços sociais. A tensão entre integração global e rediferenciação territorial, sob as atenções de Milton Santos (1996), não deixa escapar a intenção de disciplinarização das categorias geográficas; em Brenner (1998), podemos focar as relações entre as escalas geográficas e sua contínua rearrumação e territorialização, na perspectiva da resistência e da construção de referenciais emancipatórios.

Esse exercício teórico é imprescindível e também a base para enxergarmos o conteúdo territorial do tensionamento vivo da luta de classes - e não somente suas evidências geográficas - como produto do desenvolvimento do meio técnico-científico-informacional, no qual a técnica protagoniza o processo social. É imprescindível repormos o protagonismo para os sujeitos que constroem o processo social, pois somente assim um projeto para o Brasil poderá expressar os conteúdos e os desafios que se pretende pela via da emancipação do capital.

Se pudéssemos tomar aspectos que ocupam lugar central nos tempos do século XXI, a explicitação do conflito (por salário, emprego, terra, controle do processo de trabalho, moradia, reforma agrária, educação, liberdade, socialismo etc.) e os seus vínculos de pertencimento de classe nos indicariam as interações espaciais e territoriais que incidem sobre a questão emancipadora para a classe trabalhadora ou, ainda, o que é precípuo, o jogo das alianças políticas, o direcionamento e propósitos dos partidos políticos e demais organizações incumbidas de encaminhar as lutas.

A exaustão dos exemplos não pode ofuscar a objetividade de as atenções estarem direcionadas para esse movimento dialético de (des)realização e de (des)pertencimento, no qual buscamos as evidências da negação/afirmação do trabalho e da classe trabalhadora. Sejam trabalhadores formais (proletários, assalariados regulares, terceirizados etc.), além dos assalariados temporários (migrantes que vivenciam a condição de camponês/produtor familiar etc.), sejam trabalhadores informais (por conta própria, domiciliar, camelôs, ambulantes), e ainda a pluralidade de recortes (gênero, etnia etc.), o quadro plural da (re)existência do trabalho é o nosso ponto de referência.

Nessa perspectiva, a prevalência do valor trabalho e as complexidades que recaem sobre o trabalho e, em via de consequência, sobre a classe trabalhadora, repõem inúmeras situações que demandam entendimentos renovados, que nos desafiam a compreender essa nova face da polissemia do trabalho.

A desertificação social que pavimenta essa tessitura do trabalho expressa a complexa trama de relações, reveladora, pois, da profunda crise estrutural do sistema de capital, cuja urdidura induz movimentos constantes e diversificados do trabalho, por diferentes portas de entrada e de saída do tecido social.

\section{CONSIDERAÇÕES FINAIS}

A (des)realização como construto que fundamenta as formas de existência do trabalho, como expressão, por conseguinte, do movimento dialético negatividade/positividade coloca na aurora e no poente os desafios de uma riqueza temática e de assuntos que vertem para um projeto para o Brasil. Além das ações propriamente ditas protagonizadas pelos movimentos sociais, há uma farta agenda de trabalho em torno das contradições que povoam as organizações dos movimentos sociais, 
neste período de descenso, da reforma agrária, da soberania alimentar, da nucleação da produção alimentar em base camponesa, da democratização do acesso à água, das políticas públicas direcionadas para as questões vitais como saúde, educação, emprego, habitação etc.

No entanto, a expressividade dessas ações, ao longo de todo o percurso do século XXI, tem-se notabilizado nas instâncias de organização e nos movimentos sociais camponeses no Brasil e também em nível internacional, em particular nos países periféricos, que, de maneira muito mais enfática, expõem a confrontação com o capital (nas suas diferentes expressões, com predominância para o segmento agroquímico-alimentar-financeiro). Poderíamos citar o MST, o MAB, o MPA, o Movimento Camponês Popular (MCP), a Liga de Camponeses Pobres (LCP), no Brasil; e as evidências mais marcantes, na Bolívia, Equador, Filipinas, África do Sul, México, Índia e, mais recentemente, as ações protagonizadas pelos trabalhadores dos países árabes do Norte da África.

Essas e outras formas que expressam o movimento de (des)realização do trabalho, no século XXI, marcam igualmente o cenário político de novos significados para a classe trabalhadora, particularmente as explosões detonadas pelos movimentos sociais: desempregados urbanos, sem terras, atingidos por barragens, mulheres camponesas, pequenos agricultores, pescadores, posseiros, quilombolas.

A esse respeito, a constante (des)construção da identidade territorial do campesinato nos tem servido para compreender os elementos que singularizam o desenraizamento do trabalho no campo, sendo que a dinâmica dialética da constante (des)realização das formas geográficas do trabalho é apreendida por meio do fluxo constante da territorialização $\square$ desterritorialização $\square$ reterritorialização.

Por conseguinte, a recriação do campesinato não é para nós algo submerso à realidade do ser camponês, diante do processo histórico de desterritorialização/reterritorialização, ou expropriação/ recriação. É por isso que defendemos a ideia de que o campesinato faz parte do processo do metabolismo do capital e está dialeticamente ligado ao movimento mais geral da sociedade do capital, sendo que as pistas para se compreender os níveis dessas relações estão vinculadas aos mecanismos de exploração e de apropriação do excedente.

Em acordo com Antunes (2007), pensamos, com base nas pesquisas, que as diferentes formas de organização do trabalho que estão conseguindo exercer a representação dos seus interesses e, de fato, chamando para si a prerrogativa de defender os interesses dos trabalhadores, e de requerer protagonismo em nome da emancipação da sociedade do capital, é porque estão atingindo os temas vitais, como a necessidade do socialismo. Contudo, é inimaginável que o modo de controle socialista ocorra, sem que se materialize a superação da disjunção e da alienação existentes, encimada, pois, na restituição do "[...] poder de tomar decisões aos produtores associados em todas as esferas da atividade e em todos os níveis de coordenação, desde os empreendimentos locais até o mais amplo intercâmbio internacional" (MÉSZÁROS, 2010, p. 176). O autor vai mais longe, ao indicar que "[...] a reconstituição da unidade das esferas de reprodução material e política é a característica definidora essencial do modo socialista de controle sociometabólico" (p.177).

Não há mais como defender os apriorismos que tanto combatemos, pois, se hoje os movimentos sociais ocupam a cena política - apesar do descenso - e têm, efetivamente, alcançado mais amplitude organizativa e resultados concretos, nos diferentes confrontos com os setores hegemônicos, com o Estado, na sequência, podermos ter os sindicatos e, depois, os partidos e vice-versa, ou todos de forma articulada etc.

Romper com essa limitação exige que foquemos o trabalho sob novo referencial, capaz de apreender os significados geográficos das mutações em curso, no universo do trabalho (material e subjetivo), ou suas dinâmicas territoriais, conteúdos e espacialidade. Em sentido mais amplo, o trabalho, na condição de antagonista estrutural do capital, só poderá avançar sua tese/causa a partir do momento em que protagonizar postura ofensiva e não tergiversar da negação radical e na "[...] transformação positiva do modo de reprodução sociometabólica”. Assim, “[...] se os primeiros 
passos não forem dados [...] como parte orgânica da estratégia transformadora, eles nunca serão dados". Não obstante, essa renovação/mudança sociometabólica ganhará força e ossatura, quando lastreada num movimento extraparlamentar, capaz de combater a estrutura legislativa desde fora e também como força vital condicionante do próprio Parlamento, sabendo-se, pois, que o capital não é em si uma força parlamentar, como, também, enquanto "[...] capital total não pode deixar de ser uma força extraparlamentar por excelência", já que não restringe seu poder de controle metabólico às instâncias políticas (MÉSZÁROS, 2010, p. 165, 177 e 181).

É o momento de questionarmos, ainda, as limitações para apreender as capilaridades existentes entre a cidade e o campo ou, mais precisamente, entre as formas de expressão do trabalho nessas duas manifestações do tecido social, ou territórios que expressam em essência a dinâmica da sociedade e que redimensionam as reflexões sobre o universo do trabalho, o movimento operário e os movimentos sociais como um todo. Por sua vez, isso faz emergir em cena a questão do sujeito que trabalha e as dimensões (teóricas, políticas, ideológicas, sociais etc.) da classe trabalhadora, que a compõem etc.

A dificuldade em aceitar qualquer argumento que indica a limitação explicativa obstrui o debate, de sorte que essa miopia intelectual menospreza o necessário repensar da realidade objetiva e as mudanças que impõem novas contradições e redefinem os significados ontológicos dos sujeitos sociais e, consequentemente, os embates de classe. Disso poderíamos ainda extrair a seguinte reflexão: a defesa inabalável do texto original, ao invés de resguardar as formulações e tornar intocável a elaboração intelectual, nega qualquer possibilidade de diálogo, além de não comportar a dimensão dinâmica das lacunas explicativas que existem no cenário do trabalho atípico, com a denominação de suproletariado, lumpen ou "[...] estratos cada vez maiores da sociedade capitalista avançada" .

Esse assunto tem muito mais amplitude do que o apego a determinados clichês que podem não explicar o rico conteúdo geográfico das mudanças que estão ocorrendo no âmbito do trabalho e da classe trabalhadora. E não se trata, mais uma vez, de apostar nesta ou naquela corrente, fechando-se para o debate. É exatamente contra esse posicionamento que também lutamos e humildemente oferecemos nossos pensamentos, para que sejam objeto de diálogo. Por mais que se resista em assumir que a classe trabalhadora, desde o ponto de vista de determinada corrente marxista, é imexível, e a teoria que lhe dá suporte explicativo tampouco tem limitações, para nós, que estamos tentando fortalecer nossos argumentos com base nas pesquisas diretas e no acervo de informações/revelações indiretas, de outros pesquisadores, interessa a ampliação da interlocução.

De fato, essa é saída para buscarmos respostas aos problemas, superarmos as amarras e limitações teóricas, focarmos nossas argumentações na construção sustentável da autotranscendência positiva protagonizada pelos sujeitos conscientes, que buscam uma alternativa à ordem alienada. É igualmente, por suposto, uma possibilidade responsável de darmos conta de nos somarmos a outros interlocutores, rumo a um projeto para o Brasil, assumindo que a revolução social é um processo de democratização radical a ser construído pelos sujeitos (protagonistas) de autonomia radical.

A continuidade das pesquisas é o principal aporte para a afirmação dessas ações, da mesma maneira que para o contraponto em relação à negação do agrohidronegócio, das práticas de cultivo fundadas na monocultura, no entrelaçamento da commoditização sob a regência das grandes plantas processadoras (cana-de-açúcar, soja, eucalipto) e dos conglomerados agroquímico-alimentar-financeiros.

A destrutividade sistêmica, além de visível em toda parte, não dá sinais de diminuição e alimenta o repensar constante da necessária mudança radical da estrutura social e metabólica do capital.

Não obstante, o sentido palpável de tal mudança estrutural é a total erradicação do próprio capital do processo sociometabólico, ou seja, a erradicação do capital do processo metabólico da reprodução societária, porque, como sabemos, o capital é um modo de controle e isso significa que ele ou controla tudo ou implode como um sistema de controle reprodutivo da sociedade. O capital deve ser completamente erradicado e, como nos indica Mészáros (2011b), “[...] a crise estrutural 
do capital necessita de mudança estrutural”.

As soluções tangidas no século XX comprovam a incontrolabilidade do capital, quando retomamos a experiência do socialismo implantado na União Soviética e do Leste Europeu, através da derrota do capitalismo, passando pelo Welfare State, da edificação à decadência na esfera da segurança social, serviço de saúde e educação. Enfim, a realidade converteu-se na restauração do capitalismo de uma forma neoliberal regressiva, nos países da antiga União Soviética e do Leste europeu. A despeito das diferenças, essas tentativas e experiências, o que se evidencia é que todas tentaram atingir seus objetivos por "dentro da base estrutural da ordem sociometabólica estabelecida".

Se apostarmos no exercício da crítica, não hesitaríamos em acatar que experiências históricas podem nos ensinar, pois o problema não é somente almejar a derrota do capitalismo, porém, para ultrapassar sua realização instável, é necessário apostar/construir a mudança estrutural radical.

De fato, se a construção de um projeto para o Brasil não pressupõe a superação do sociometabolismo do capital e da emancipação da classe trabalhadora, de nada valeria o diálogo junto aos interlocutores, que requerem de nós conhecimentos renovados/atualizados, diante das novas realidades do trabalho, em meio às fragilidades e insuficiências do debate teórico sobre classes sociais. Recolocar em cena a dimensão de classe e a luta de classes, permeada pelo ambiente político, sindical e acadêmico, é a via privilegiada para ajudarmos a cunhar um conceito de classe trabalhadora com alcance e potência explicativa para elucidar a dinâmica geográfica do trabalho e sua expressão, nos territórios em disputa ou, mais efetivamente, o processo de construção cotidiana da resistência e da emancipação/revolução.

A inseparabilidade objetiva dos indivíduos da urdidura social que vivem torna inevitável a extensão global do processo de reprodução societal impõe que o controle consciente do metabolismo social seja não somente uma possibilidade senão que condição fundante da sobrevivência humana.

Afinal de contas, o que queremos com esta discussão sobre um projeto para o Brasil que não contenha ímpeto emancipatório?

\section{REFERÊNCIAS BIBLIOGRÁFICAS}

ANTUNES, R. (Org.). Os sentidos do trabalho. São Paulo: Boitempo, 1999.

ANTUNES, R. Dimensões da precarização estrutural do trabalho. In: DRUCK, G; FRANCO, T. A. (Org.). Perda da razão social do trabalho. São Paulo: Boitempo, 2007. p. 13-22.

ANTUNES, R. Século XXI: nova era da precarização estrutural do trabalho" In: ANTUNES R.; BRAGA, R. Infoproletários - degradação real do trabalho virtual. São Paulo: Boitempo, 2009. p.231-238.

ANTUNES, R. O sistema de metabolismo social do capital e seu corolário, a alienação, na obra de István Mészáros. In: NOBILE, R.; JUNKINGS, I. (Org.). István Mészáros e os desafios do tempo histórico. São Paulo: Boitempo, 2011. p.75-88.

BEAUD, S.; PIALOUX, M. Retorno à condição operária. São Paulo: Boitempo, 2009.

BRENNER, R. The economics of global turbulence. New Left Review, London, n.229, May/June, 1998.

CASTILLO, J. J. Sociologia del trabajo. Madri: Siglo Veintiuno, 1996.

CHESNAIS, F. Não só uma crise econômica e financeira, uma crise de civilização. In: NOBILE, R.; JUNKINGS, I. (Org.). István Mészáros e os desafios do tempo histórico. São Paulo: Boitempo, 2011. p.187-198. HARVEY, D. Condição pós-moderna. São Paulo: Loyola, 1992.

HUWS, U. The making a cybertariat: virtual work in a real world. London: Merlin Press, 2004.

HUWS, U. Fixo, volátil ou dividido: o trabalho, a identidade e a divisão espacial do trabalho no Século XXI. London, 2006. Disponível em: $<$ www.resistir.info $>$ Acesso em: 29 out. 2006. [Originariamente em inglês. Disponível em: www.monthlyreview.org0306huws.htm. 7p.]

HUWS, U. The spark in the engine: creative workers in a global economy. Work organisation labour and globalisation, London, v.1, n.1, Jan., p. 1-12, 2007. 
HUWS, U. A construção de um cibertariado? Trabalho virtual num mundo real. In: ANTUNES, R.; BRAGA, R. (Orgs.). Infoproletários - Degradação real do trabalho virtual. São Paulo: Boitempo, 2011. p.37-58. LESSA, S. Trabalho e proletariado no capitalismo contemporâneo. São Paulo: Cortez, 2007.

LESSA, S. Centralidade ontológica do trabalho e centralidade política proletária. Lutas Sociais, São Paulo, n.13/14, p. 106-121, 2005.

LOURENÇO, E. A. S. Na trilha da saúde do trabalhador: a experiência de Franca. Franca: UNESP/ Franca, 2009.

LÖWY, M. A natureza e o meio ambiente: os limites do planeta. In: MENEGAT, M.; FONTES, V.; BEHRING, E. R. Dilemas da Humanidade - diálogo entre civilizações. Rio de Janeiro: Contraponto, 2008.

LUXEMBURGO, R. A acumulação de capital. Rio de Janeiro: Zahar, 1976.

MARX, K. O capital. Rio de Janeiro: Civilização Brasileira, 1982.

MARX, K.; ENGELS, F. Obras escolhidas. Moscou: Progresso, 1982. Tomo 1.

MENEGAT, M. A face e a máscara: a barbárie da civilização burguesa. Revista Pegada, Presidente Prudente, v.8, n.2, dez., p.27-46, 2007.

MCDOWELL, L. Thinking through class and gender in the context of working class studies. Antipode, Leeds, v.40, n.1, 2008. p. 21-24.

MÉSZÁROS, I. Para além do capital. São Paulo: Boitempo, 2002.

MÉSZÁROS, I. O poder da ideologia. São Paulo: Boitempo, 2004.

MÉSZÁROS, I. O desafio e o fardo do tempo histórico. São Paulo: Boitempo, 2007.

MÉSZÁROS, I. A atualidade histórica da ofensiva socialista. São Paulo: Boitempo, 2010.

MÉSZÁROS, I. Estrutura social e formas de consciência II. São Paulo: Boitempo, 2011a.

MÉSZÁROS, I. Crise estrutural necessita de mudança estrutural. Salvador, 2011b. 12p. (mimeo.).

MOREIRA, R. Pensar e ser em geografia. São Paulo: Contexto, 2007.

RANIERI, J. A câmara escura. São Paulo: Boitempo, 2001.

RICKLEFS, R. E. A economia da natureza. Rio de Janeiro: Guanabara Koogan, 2009.

SANTOS, M. Técnica, espaço, tempo. São Paulo: Hucitec, 1996.

WACQUANT, L. As duas faces do gueto. São Paulo: Boitempo, 2008.

THOMAZ JÚNIOR, A. Por trás dos canaviais, os nós da cana. São Paulo: Annablume/FAPESP, 2002.

THOMAZ JÚNIOR, A. Não há nada de novo sob o sol num mundo de heróis! (A civilização da barbárie na agroindústria canavieira). Revista Pegada, Presidente Prudente, v. 8, p. 5-25, 2007.

THOMAZ JUNIOR, A. Dinâmica geográfica do trabalho no século XXI. (Limites explicativos, autocrítica e desafios teóricos). 997p. Tese (Livre Docência) - Faculdade de Ciências e Tecnologia, Universidade Estadual Paulista, Presidente Prudente, 2009.

THOMAZ JÚNIOR, A. O agrohidronegócio no centro das disputas territoriais e de classe no Brasil do Século XXI. Campo Território, V. 5, N 10, Uberlândia, 2010.

VASAPOLLO, L. O trabalho atípico e a precariedade. São Paulo: Expressão Popular, 2005.

VASAPOLLO, L. Por uma política de classe. São Paulo: Expressão Popular, 2007.

Trabalho enviado em agosto de 2011

Trabalho aceito em outubro de 2011 